\title{
Cytochrome b mitochondrial DNA characteristic from non-invasive samples of wild population Javan Banteng (Bos javanicus d'Alton, 1823)
}

\author{
MARYATUL QIPTIYAH ${ }^{1,3, \bullet}$, SATYAWAN PUDYATMOKO ${ }^{2}$, AYPBC WIDYATMOKO ${ }^{3}$, \\ MUHAMMAD ALI IMRON ${ }^{2}$, ILG NURTJAHJANINGSIH ${ }^{3}$ \\ ${ }^{1}$ Doctoral Program in Forestry Science, Faculty of Forestry, Universitas Gadjah Mada. J1 Agro No.1, Bulaksumur, Sleman 55281, Yogyakarta, Indonesia. \\ ${ }^{2}$ Faculty of Forestry, Universitas Gadjah Mada. Jl Agro No.1, Bulaksumur, Sleman 55281, Yogyakarta, Indonesia \\ ${ }^{3}$ Center for Biotechnology and Tree Improvement Research and Development. Jl. Palagan Tentara Pelajar Km. 15, Purwobinangun, Pakem, Sleman \\ 55582, Yogyakarta, Indonesia. Tel./fax. +62-274-896080, `email: maryatulqiptiyah@ biotifor.or.id
}

Manuscript received: 16 August 2018. Revision accepted: 14 January 2019.

\begin{abstract}
Qiptiyah M, Pudyatmoko S, Widyatmoko AYPBC, Nurtjahjaningsih ILG, Imron MA. 2019. Cytochrome-b mitochondrial DNA characteristic from non-invasive samples of wild population Javan Banteng (Bos javanicus d'Alton, 1823). Biodiversitas 20: $350-355$. Javan banteng (Bos javanicus javanicus) is one of the protected big mammals in Indonesia, due to its population decline. The main populations of Javan banteng are currently in Ujung Kulon National Park (UKNP), Alas Purwo National Park (APNP), Meru Betiri National Park (MBNP) and Baluran National Park (BNP). These four remaining populations are fragmented with wide geographical distances. Population reduction and fragmentation between populations can promote depletion of genetic characters. This study aim to examine the genetic characteristics of Javan banteng based on cytochrome b region of mitochondrial DNA. Genetic materials were obtained by a non-invasive method (feces) from four national parks in Java.The sequencing results were aligned with cytochrome $b$ mitochondrial DNA sequences from the other banteng (B. j. lowi and B. j. birmanicus) from the GeneBank sequence database. The results from this study revealed that the genetic distance of Javan banteng between UKNP, APNP, and BNP were 0, while the genetic distance between these populations with MBNP was 0.005. Moreover, the population of MBNP has only one haplotype that does not exist in the other populations. Based on these results, there should be caution in conducting genetic infusion of Javan banteng in their natural populations, especially in Meru Betiri National Park.
\end{abstract}

Keywords: Cytochrome b, fecal, genetic network, Javan banteng, national park

\section{INTRODUCTION}

Banteng (Bos javanicus D'Alton, 1823) is one of large mammals in Indonesia categorized as endangered species based on IUCN RedList (Gardner et al. 2016). Three subspecies are recognized and distributed in Myanmar, Thailand, Laos, Vietnam, Cambodia, Malaysia (Bos javanicus birmanicus), Borneo (Bos javanicus lowi) and Java (Bos javanicus javanicus) (Hoogerwerf 1970; Castello 2016). Javan banteng distribution is spread in several regions in Java Island. The current populations are mainly located in conservation areas such as national parks. In western Java, they can be found in Ujung Kulon National Park (UKNP), and it is easy to encounter directly (Hoogerwerf 1970; Kuswanda 2005). In eastern Java, this species is spread over three national parks, including Meru Betiri National Park (MBNP), Alas Purwo National Park (APNP) and Baluran National Park (MBNP) (Pudyatmoko and Djuwantoko2006, Pudyatmoko et al 2007, Garsetiasih et al. 2012; Hakim et al. 2015; Imron et al. 2016; Pudyatmoko 2017).

The natural habitat of banteng is in lowland forest with various habitat types such as grasslands, shrubs, forests and seaside for salting (Whitten et al. 1996; Gardner 2014; Gardner et al. 2016; Imron et al. 2016). Unfortunately, banteng populations are declining and fragmented in some areas (Pudyatmoko et al. 2007). In the Alas Purwo National
Park, banteng was distributed only on an area with having high habitat suitability index (Imron et al. 2016). Today, the species is rarely found in Baluran NP and Meru Betiri NP. Sharp population decline and habitat fragmentation can affect genetic characteristics of wildlife in general, including banteng (Allendorf and Luikart2007). Thus, the genetic approach becomes important to support conservation efforts.

Collection of genetic material is the first step for animal genetic research, whether by invasive or non-invasive technique. The conventional invasive samples are blood or tissue, while non-invasive samples are hair or feces (Lukas, 2008). The non-invasive genetic sampling methods are the most feasible method for wildlife animals, especially shy, elusive, rare and endangered animals. This method does not require a direct encounter with target animal, so it is unobtrusive and harmless (Baldwin et al. 2010). Genetic analysis using non-invasive samples have been applied to several studies with different purposes and species such as tigers (Mondol et al. 2009), elephants (Flagstad et al. 2012; Hedges et al. 2013; Moßbrucker et al. 2015), gorilla groups (Arandjelovic et al. 2010), and orangutan (Nater et al. 2013). So far, the non-invasive genetic sampling for banteng was conducted for Bornean banteng and very limited information involving the use of this method for Javan banteng, in their natural habitat (Gardner 2014; Matsubayashi et al. 2014). 
The mitochondrial DNA is derived maternally and without any recombination with the male parent (Allendorf and Luikart2007). Mitochondrial DNA can be used as a tool for analyzing genetic diversity and phylogenetic relationships (Sawaimul et al. 2014). Studies of banteng haplotypes in some areas have been documented. In Cambodia, studies using mitochondrial DNA were used to address the taxonomy problem of kouprey (Bos sauveli), which is a hybrid between banteng (B. javanicus) and zebu (Bos taurus indicus) (Hassanin et al. 2006; Hassanin and Ropiquet 2007). Mitochondrial DNA was also applied to reveal the genetic structure of d-loop section between banteng and Bali cattle (Wisesa et al. 2012), as well as the possibility of genetic introgressions between wild banteng in Borneo and domestic cattle in the past (Matsubayashi et al. 2014).

Cytochrome $\mathrm{b}$ is one of the regions in mitochondrial DNA which commonly used in wildlife genetic analysis. This study aimed to describe cytochrome $b$ region of mitochondrial DNA characteristics of wild banteng using non-invasive (fecal) material from four national parks in Java and a semi in-situ captivity in Baluran. We hypothesize that there will be variations in the cytochrome $b$ region of mitochondrial DNA through the distribution of haplotypes between sites, in context of geographical distances and habitat fragmentation.

\section{MATERIALS AND METHODS}

\section{Study area}

The samples from UKNP were collected from two feeding ground sites, namely Cigenter and Cidaon; MBNP samples were acquired from Pring Tali feeding ground, Bande Alit plantation and adjacent area, APNP samples collected from Sadengan feeding ground and Jati Papak (Kucur) meadows. Meanwhile, in BNP samples were collected from Bekol, Bama, Semiang, Talpat and Sirontoh. Location coordinates were recorded for each sampling site. Samples were collected at known location with frequently of banteng encounter. The distance between west and east population is about 1000 kilometers. In addition, to using samples from populations in natural habitats, also used samples from semi in-situ enclosures in BNP. Sampling was conducted in September 2015 and September 2016, when rainfall intensities were low, to minimize degradation and the loss of intestinal epithelial cells (Farrel et al. 2000; Lampa et al. 2008; Brinkman et al. 2010). Genetic materials were collected from the outer surface of fresh feces to diminish inhibitors (Waits and Paetkau 2005). Samples were preserved using absolute ethanol prior to DNA isolation that was conducted in the Molecular Genetic Laboratory of Center for Forest Biotechnology and Tree Improvement Research and Development, Yogyakarta, Indonesia.

\section{Procedures}

DNAs were isolated from feces using the QiaAmp Stool Mini Kit from QIAGEN following the manufacturer's protocol with modification of ASL buffer incubation time (24-48 hours) according to Mondol et al. (2009) and Gardner (2014). The modification at the incubation stage is intended to increase the quantity of DNA. Amplifications of DNA target through PCR were proceeded by using a primer pair of 1F (ATC CTC ACG GTA CTA TTC CTA GCA ATA CA) and 1R (GGT AAG GGT TGT TTT TC TGA GAA TC) that targeted cytochrome b region (Gardner 2014).

The PCR reactants were made in $50 \mu \mathrm{l}$ volumes, consisting of 50 ng DNA; 1X KAPA 2G Fast Ready Mix; $0.1 \mathrm{mg}$ BSA; $0.25 \mathrm{mM}$ for each primer and Psd H2O up to $50 \mu$. Amplification was done by pro Flex PCR System machine. Pre-denaturation conditions were at $94{ }^{\circ} \mathrm{C}$ for 5 minutes, continued with 35 main cycles, including denaturation stage at $94{ }^{\circ} \mathrm{C}$ for 30 seconds, annealing stage at $55^{\circ} \mathrm{C}$ for 30 seconds and extension stage at $72{ }^{\circ} \mathrm{C}$ for 1 minute 30 seconds. The entire process ended with a final extension at $72{ }^{\circ} \mathrm{C}$ for 7 minutes. The PCR products were visualized using $1.5 \%$ agarose gel run electrophoretically at $120 \mathrm{~V}$ about 60 minutes followed by staining it with ethidium bromide. The results of DNA amplification through the PCR process will appear at a size of $395 \mathrm{bp}$.

Samples that failed to amplify were rejected, the succeeding ones were partially sequenced using the Big Dye Terminator v3.1 Cycle Sequencing Kit and ABI PRISM 3730xl Genetic Analyzer (Applied Biosystem, USA) machine. The sequencing results were matched with reference sequences that have already available in the NCBI (National Center for Biotechnology Information) database using GenBank standard Nucleotide Basic Local Alignment Tool (BLAST). The BLAST results that were not identical to the Javan banteng sequence were not used in the analysis.

\section{Data analysis}

The nucleotide sequences were aligned with cytochrome $\mathrm{b}$ sequences from other subspecies/species retrieved from the reference database using CLUSTAL W on BioEdit 7 software (Hall 1999) and edited manually to determine its accuracy. The reference sequences are taken from other members of Bovidae group from the NCBI database (http://www.ncbi.nlm.nih.gov), with accession numbers (Table 1) according to Matsubayashi et al. (2014). The unequal nucleotide length was cut so that the overall size of the sample length became equal. The genetic distance was calculated using Neighbor-joining method on MEGA 7 software (Kumar et al. 2016). Outgroup in this analysis was using water buffalo, Bubalus bubalis (JQ241279) (Matsubayashi et al. 2014). A Median-joining network analysis (Bandelt et al. 1999) was using all Javan banteng partial cytochrome $b$ sequences. The haplotype network was drawn using NETWORK v5.0.0.0. An epsilon value used in this network was zero for all sequences 0 (http://www.fluxus-engineering.com, last accessed on March 15, 2018). 


\section{RESULTS AND DISCUSSION}

DNA sequences of cytochrome $b$ region of the Javan banteng (UKNP, $\mathrm{n}=8$; MBNP, $\mathrm{n}=3$; APNP, $\mathrm{n}=10$; $\mathrm{BNP}$, $\mathrm{n}=12$; Semi in-situ captive, $\mathrm{n}=3$ ) and reference sequences derived from the NCBI database (344 bp length) were aligned. Samples used in semi in-situ captivity are limited to the parent only. Offspring was not sampled because theoretically their cytochrome $b$ character definitely identical to maternal parent. There were two DNA sequences from the BNP samples which were not continued in the analysis process, because the BLAST results showed that the samples were closer to the buffalo, compared to banteng.

The alignment results showed that 17 polymorphic sites of the entire sequence (Javan banteng and reference sequences) were observed. However, only three polymorphisms were found, at positions 163, 340 and 344 (Table 2), specifically on Javan banteng (from four natural populations and a semi in-situ captivity in Java). These polymorphisms were indicated by the substitution of base $\mathrm{T}$ to $\mathrm{C}$ at position 163, base $\mathrm{A}$ to $\mathrm{C}$ at position 340 and base $\mathrm{C}$ to $\mathrm{A}$ at position 344 . These polymorphic numbers were lower than that of the Bornean banteng who have eight polymorphic sites (Gardner 2014). These indicate that the cytochrome $b$ variation of Javan banteng was low and this may due to low number of female parents with low genetic variations. Mitochondrial DNA, including the region of cytochrome $\mathrm{b}$ is derived from the maternal line. Other literature suggests that low-level variations in mitochondrial DNA are affected by limited founder individual (Allendorf and Luikart 2007).

The median-joining network was constructed to represented haplotype relationship between the four populations using all sequences partial of cytochrome $b$ sequences of Javan banteng (Figure 1). The network shows prominent star-shaped with haplotype 1 (H1) had highest frequency of cytochrome b sequences (24 samples). The haplotype 3 (H3) was the second highest frequency (8 samples), while haplotype 2 (H2) has three samples and haplotype 4 (H4) has only one sample. Differences between haplotypes only occur in one substitution, the substitution of which has a variety of types and location of nucleotide bases.

Our finding of network type on Javan banteng is similar to the Bornean banteng that also represented star-shaped. This star-shapes is a type of population that have undergone recent demographic expansion (Gardner 2014). The cytochrome $b$ haplotype network that we found shows connection between haplotypes. The low-frequency haplotype are connected by one substitution to the common haplotype. The distribution of Javan banteng haplotype based on partial cytochrome $b$ sequences from four national park in Java represented in Figure 2. Most of the samples were categorized as haplotype 1 and they were distributed in three national parks (UKNP, APNP, and BNP). The second highest proportion of haplotype in this network (H3), were distributed also in three national parks similar to
H1. The H2 was a specific haplotype that was found only in MBNP, and the other specific haplotype (H4), was found only in UKNP. The Javan banteng kept in a semi in-situ captivity in BNP were belonged to $\mathrm{H} 1$.

Table 1. GenBank accession number of Banteng and the other Bovidae

\begin{tabular}{ll}
\hline Name on tree & $\begin{array}{l}\text { Accession number of } \\
\text { GeneBank }\end{array}$ \\
\hline B. javanicus_reff & $\mathrm{D} 82889$ \\
B. javanicus lowi $\mathrm{H} 1$ & $\mathrm{AB} 703046$ \\
B. javanicus lowi $\mathrm{H} 2$ & $\mathrm{AB} 703047$ \\
B. javanicus birmanicus CKM4 & $\mathrm{EF} 685912$ \\
B. javanicus birmanicus CKM23 & $\mathrm{EF685913}$ \\
B. bubalis $\mathrm{H}$ RBB1 & $\mathrm{JQ} 241279$ \\
\hline
\end{tabular}

Table 2. Nucleotide polymorphism of partial sequences on cytochrome $b$ from Javan banteng

\begin{tabular}{|c|c|c|c|c|}
\hline Sample's name & $\begin{array}{c}\text { Population } \\
\text { source }\end{array}$ & 163 & 340 & 344 \\
\hline Cigenter 02 & UKNP & $\mathrm{T}$ & A & $\mathrm{C}$ \\
\hline Cigenter 12 & UKNP & . & . & . \\
\hline Cidaon 21 & UKNP & . & . & A \\
\hline Cidaon 38 & UKNP & . & . & . \\
\hline Meru Betiri 03 & MBNP & $\mathrm{C}$ & . & . \\
\hline Meru Betiri 08 & MBNP & $\mathrm{C}$ & . & . \\
\hline Meru Betiri 12 & MBNP & $\mathrm{C}$ & . & . \\
\hline Kucur 17 & APNP & . & . & . \\
\hline Sadengan 04 & APNP & . & . & . \\
\hline Sadengan 11 & APNP & . & . & . \\
\hline Sadengan 23 & APNP & . & . & . \\
\hline Doni (Semi in situ) & Semi in situ & . & . & . \\
\hline Tina (Semi in situ) & Semi in situ & . & . & . \\
\hline Usi (Semi in situ) & Semi in situ & . & . & . \\
\hline Bekol 06 & BNP & . & . & . \\
\hline Palongan 01 & $\mathrm{BNP}$ & . & . & . \\
\hline Bekol 01 & BNP & . & $\mathrm{C}$ & . \\
\hline HM 57-01 & $\mathrm{BNP}$ & . & $\mathrm{C}$ & . \\
\hline HM 57-02 & BNP & . & . & . \\
\hline HM 57-03 & $\mathrm{BNP}$ & . & . & . \\
\hline HM 57-05 & BNP & . & $\mathrm{C}$ & . \\
\hline Palongan 02 & BNP & . & . & . \\
\hline Palongan 03 & $\mathrm{BNP}$ & . & - & . \\
\hline Palongan 04 & $\mathrm{BNP}$ & . & . & . \\
\hline Palongan 05 & BNP & . & . & . \\
\hline Palongan 08 & BNP & . & $\mathrm{C}$ & . \\
\hline Kucur 02 & APNP & . & . & . \\
\hline Kucur 05 & APNP & . & $\mathrm{C}$ & . \\
\hline Kucur 19 & APNP & . & . & . \\
\hline Kucur 38 & APNP & . & $\mathrm{C}$ & . \\
\hline Kucur 40 & APNP & . & . & . \\
\hline Cigenter 10 & UKNP & . & . & . \\
\hline Cigenter 11 & UKNP & . & . & . \\
\hline Cigenter 13 & UKNP & . & $\mathrm{C}$ & . \\
\hline Cidaon 03 & UKNP & . & . & . \\
\hline Sadengan 56 & APNP & . & $\mathrm{C}$ & \\
\hline
\end{tabular}




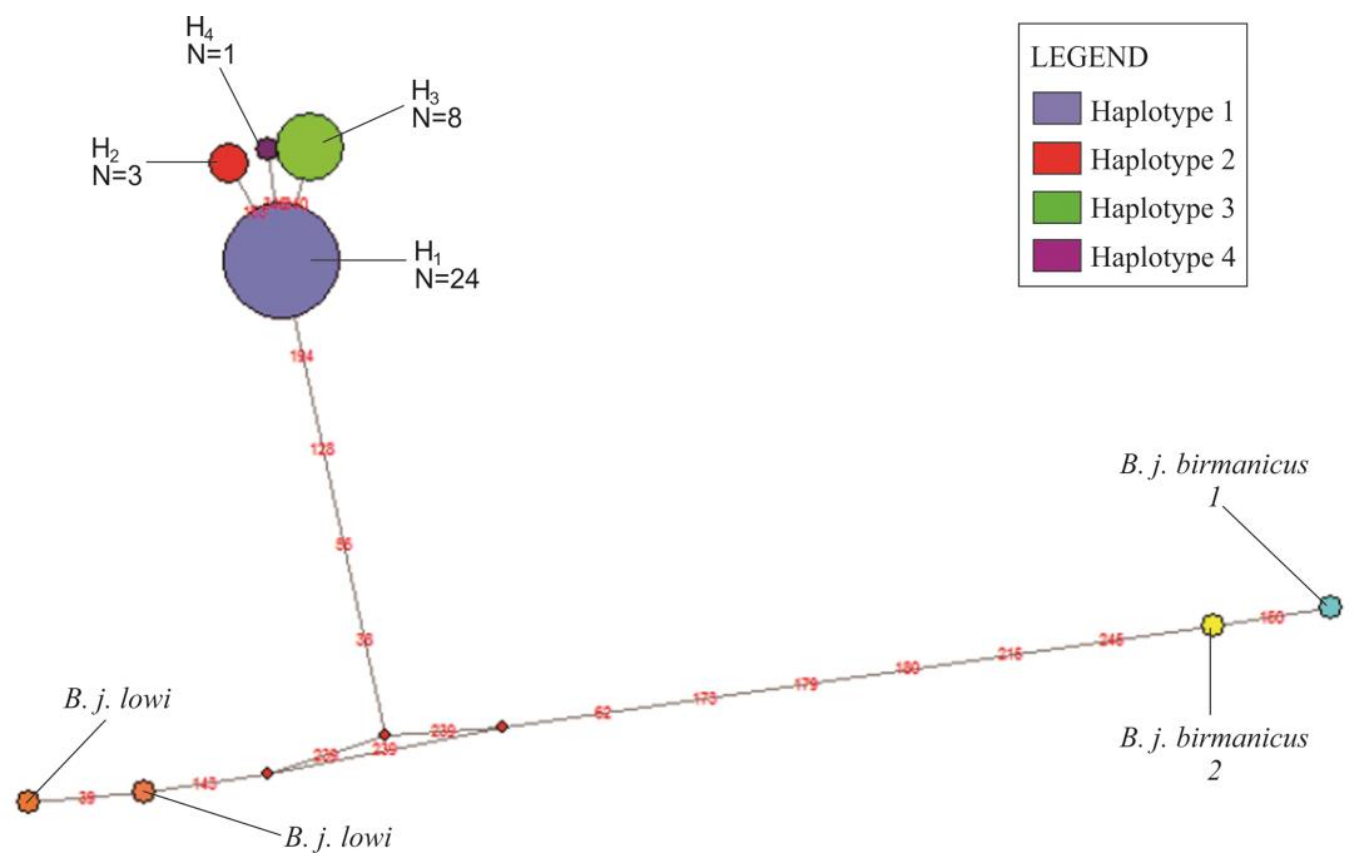

Figure 1. The median-joining network of Javan banteng haplotype and compared with other sub-species of banteng in South East Asia. Four haplotypes were distinguished from four polymorphic sites at positions 163, 340 and 344 bp: H1: T A C; H2: C A C; H3: T C C; H4: T A A

We found haplotype similarity among three national parks, where their locations were fragmented and separated by hundreds of kilometers. The hypothesis imposed for this finding is that the three populations of the park have the same maternal lineage. In the past, the Javan banteng was distributed in several continuous habitats in Java as reported by Hogerwerf (1970) from Sampung cave near Ponorogo, mount Kelud, mount Kawi, the area between Tengger and Semeru mountain, also in Bandjaran Jepara, north of Mount Muria in 1853. However, once fragmentation occurred, wild banteng in Java is distributed on locations that only have coastal area. This is because the banteng is a wild animal that needs salting by drinking sea water to meet the physiological process (Imron et al 2016).

Geographically, the four national parks can be divided into two regions, namely UKNP in western Java and MBNP, APNP, BNP in eastern Java. However, we found a specific haplotype in MBNP that has a much closer geographically range to APNP and BNP. MBNP does not have any haplotypes owned by other national parks, although MBNP has a much closer range with APNP, compared to APNP distance with UKNP. This can be explained by the hypothesis: (1) banteng migration suspected of having separate lines. Founders who perform migration to MBNP are different from founders in other locations. Thus, banteng in MBNP has different haplotypes than those found in APNP and BNP. (2) In addition, the least number of haplotypes encountered in MBNP can also be suspected because of very small sample encounter. The small number of samples was due to the conflict between banteng and people by evicting banteng from the cocoa and coffee plantation in Bande Alit enclave area using fireworks, so that both banteng and representative samples for DNA analysis became difficult to find.

The specific haplotype only found in MBNP and not found in other habitats. This result supported by mismatch analyses using NETWORK v5.0.0.0 program that showed bimodal mismatch distribution. The current populations were derived from two population's origin. First population origin generates the recent populations that have the same haplotypes (H1 and H3) in UKNP, APNP, and BNP. The second population origin generates the current population with specific haplotype (H2) in MBNP.

All national park locations even though the geographical distance is quite far, but not always followed by differences in genetic distance. The samples of three national parks have a very low genetic distance $(0,000)$. The zero value of genetic distance due to the small sequences variations between individual samples. More variations of partial cytochrome $\mathrm{b}$ sequences were found only in a sample from UKNP. MBNP samples have a slightly lower distance (0.005) to the previous three locations (Table 3). The results of this genetic distance mean that Javan banteng populations at three national park (UKNP, APNP, and BNP) are more related to each other than to MBNP. Sawitri et al. (2014) that previously found the genetic distance of banteng in MBNP to ex-situ conservation institution's population in Indonesia also low $(0,004)$, even though based on the variation of d-loop region. Although both studies were used different regions of mitochondrial DNA, the results obtained have an equivalent range of genetic distance value. This indicates that the DNA mitochondria of the banteng which in Meru Betiri National Park is the most different compared to banteng that found in other areas. 


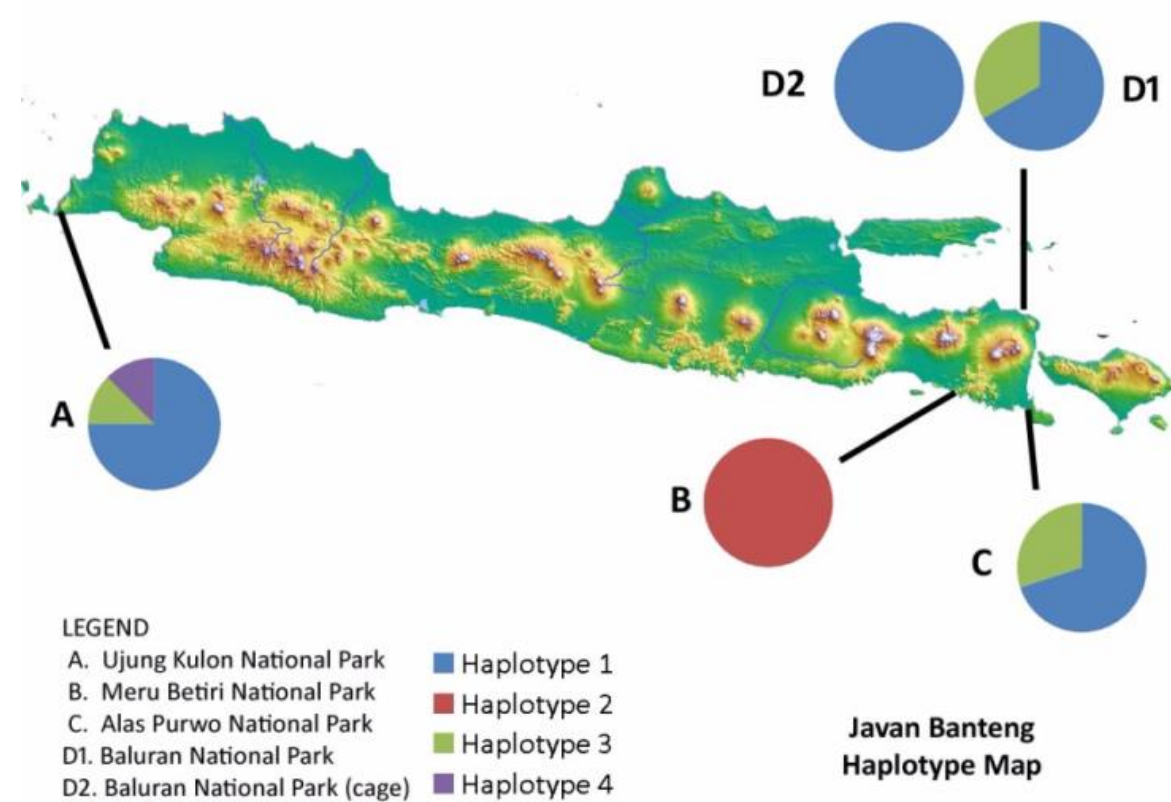

Figure 2. Haplotype distribution of Javan banteng in wild population

Table 3. Genetic distance Javan banteng from the various population and compared with other bantengs

\begin{tabular}{|c|c|c|c|c|c|c|c|c|c|}
\hline & UKNP & MBNP & APNP & Cage & BNP & B. j.birmanicus & Reff & B. j.lowi & Outgroup \\
\hline UKNP & - & & & & & & & & \\
\hline MBNP & 0.005 & - & & & & & & & \\
\hline APNP & 0.000 & 0.005 & - & & & & & & \\
\hline Cage & 0.000 & 0.005 & 0.000 & - & & & & & \\
\hline BNP & 0.000 & 0.005 & 0.000 & 0.000 & - & & & & \\
\hline B. j. birmanicus & 0.047 & 0.053 & 0.047 & 0.047 & 0.047 & - & & & \\
\hline Reff & 0.000 & 0.005 & 0.000 & 0.000 & 0.000 & 0.047 & - & & \\
\hline B. j. lowi & 0.030 & 0.035 & 0.030 & 0.030 & 0.030 & 0.033 & 0.030 & - & \\
\hline Outgroup & 0.207 & 0.215 & 0.207 & 0.207 & 0.207 & 0.191 & 0.207 & 0.187 & - \\
\hline
\end{tabular}

Low genetic distance between haplotype was also observed in other research. A study by Matsubayashi et al (2014) that obtained fairly close genetic distance (0.004) based on the cytochrome region $b$, both between Bornean banteng and between Burma banteng haplotype. Research on Asian elephants by Fleischer et al. (2001) also found a low genetic distance between clades (0.004). Meanwhile, genetic distance between population of Javan banteng in this study was lower if compared with other banteng subspecies (B. j. lowi and B. j. birmanicus) (Table 3). This result means that all the population of Javan banteng is still closely related. Although the population has been fragmented, it is likely that the isolation level has not been long enough so that it has not produced sufficiently clear divergence.

The specific haplotype found in MBNP has implication to conservation strategy. This haplotype has a substitution of $\mathrm{T}$ to $\mathrm{C}$ at the position 163 of partial cytochrome $\mathrm{b}$ sequences (344bp) and was not found in the other samples from the other national parks. None of any sample of Javan banteng in MBNP has any haplotypes that exist in the other national parks. Several considerations can be imposed in conserving banteng based on cytochrome $b$ mitochondrial DNA. MBNP can serve separate conservation unit from other national parks, to maintain DNA purity. However, on the other side, if the population decline is getting worse, efforts to increase genetic diversity should also be considered to avoid inbreeding and genetic drift.

The partial cytochrome $b$ sequences are part of mitochondrial DNA that only inherited from maternal lineage without recombination, which describes evolution in certain species. Meanwhile, the genetic diversity between populations determined from mating can be analyzed based on nuclear DNA. Both genetic analyzes, mitochondria DNA and nuclear DNA are used for translocation and reintroduction programs. Thus, genetic assessment base on the nuclear genome is still needed to provide complete information about the molecular genetics of wild Javan banteng, as has been done on the elephants 
(Flagstad et al. 2012; Hedges et al. 2013; Moßbrucker et al. 2015).

\section{ACKNOWLEDGMENTS}

This research was funded by the Ministry of Environment and Forestry (Grant Number DIPA029.07.2.568352/2015 and DIPA-029.07.2.568352/2016). We would like to thank field guide assistants for the supports on the collections of material genetics which were provided by UKNP, MBNP, APNP, and BNP. We also thank to the Copenhagen Zoo that provides assistance during sampling in BNP.

\section{REFERENCES}

Allendorf F, Luikart GH. 2007. Conservation and the Genetics of Populations. Blackwell Publishing, New York.

Arandjelovic M, Head J, Kuhl H, Boesch C, Robbins MM, Maisels F, Vigilant L. 2010. Effective non-invasive genetic monitoring of multiple wild western gorilla groups. Biol Conserv 143 (7): 17801791.

Bandelt H-J, Forster P, Röhl A. 1999. Median-joining networks for inferring intraspecific phylogenies. Mol Biol Evol 16:37-48.

Baldwin HJ, Hoggard SJ, Snoyman ST, Stow AJ, Brown C. 2010. Noninvasive genetic sampling of faecal material and hair from the greyheaded flying-fox (Pteropus poliocephalus). Austr Mammal 32: 5661.

Brinkman TJ, Schwartz MK, Person DK, Pilgrim KL, Hundertmark KJ. 2010. Effects of time and rainfall on PCR success using DNA extracted from deer fecal pellets. Conserv. Genet. 11: 1547-1552.

Castello JR. 2016. Bovids of the World. Antelopes, Gazelles, Cattle, Goats, Sheep, and Relatives. Princeton University Press, MA.

Farrel LA, Roman J, Sunquist ME. 2000. Dietary separation of sympatric carnivores identified by molecular analysis of scats. Molecular Ecology 9: 1583-1590.

Flagstad Ø, Pradhan NMB, Kvernstuen LG, Wegge P. 2012. Conserving small and fragmented populations of large mammals: Non-invasive genetic sampling in an isolated population of Asian elephants in Nepal. J Nat Conserv 20: 181-190.

Fleischer RC, Perry EA, Muralidharan K, Wemme CM. 2001. Phylogeography of the Asian elephant (Elephas maximus) Based on mitochondrial DNA. Evolution 55 (9): 1882-1892.

Gardner PC. 2014. The natural history, non-invasive sampling, activity patterns and population genetic structure of the Bornean banteng Bos javanicus lowi in Sabah, Malaysian Borneo. [Dissertation]. Cardiff University, UK.

Gardner P, Hedges S, Pudyatmoko S, Gray TNE, Timmins RJ. 2016. Bos javanicus. The IUCN Red List of Threatened Species 2016: e.T2888A46362970. DOI: 10.2305/IUCN.UK.20162.RLTS.T2888A46362970.en.

Garsetiasih R, Alikodra HS, Soekmadi R, Bismark M. 2012. Potensi dan Produktivitas Habitat Pakan Banteng (Bos javanicus d'Alton 1832) di Padang Perumputan Pringtali dan Kebun Pantai Bandealit Taman Nasional Meru Betiri Jawa Timur. Jurnal Konservasi Hutan dan Pelestarian Alam 9 (2): 113-123. [Indonesian]

Hall TA. 1999. BioEdit: a user-friendly biological sequence alignment editor and analysis program for Windows 95/98/NT. Nucleic Acids Symp Ser 41: 95-98.

Hassanin A, Ropiquet A, Cornette R, Tranier M, Pfeffer P, Candegabe P, Lemaire M. 2006. Has the kouprey (Bossauveli Urbain, 1937) been domesticated in Cambodia? Comptes Rendus Biologies 329 (2): 124 35.

Hassanin A, Ropiquet A. 2007. What is the taxonomic status of the Cambodian banteng and does it have close genetic links with the kouprey? J Zool 271: 246-252.

Hedges S, Johnson A, Ahlering M, Tyson M, Eggert LS. 2013. Accuracy, precision, and cost-effectiveness of conventional dung density and fecal DNA based survey methods to estimate Asian elephant (Elephas maximus) population size and structure. Biol Conserv 159: 101-108.

Hoogerwerf A. 1970. Udjung Kulon, the land of the last Javan rhinoceros. With local and general data on the most important faunal species and their preservation in Indonesia. E.J. Brill, Leiden.

Imron MA, Hastuti HM, Satria RA, Ashari M, Rudijanta, Nurvianto S, Subeno, Pudyatmoko S. 2016. The Use of Habitat Suitability Index Map for Designing Population Monitoring of Banteng (Bosjavanicus) in Alas Purwo National Park-East Java-Indonesia, Asian J Conserv Biol 5 (1): 31-39.

Kumar S, Stecher G, Tamura K. 2016. MEGA7: Molecular evolutionary genetics analysis Version 7.0 for Bigger Datasets. Mol Biol Evol 33 (7): $1870-1874$

Kuswanda W. 2005. Analisis Karakteristik dan Pengelolaan Populasi Banteng (Bos javanicus d'Alton, 1832) di Padang Penggembalaan Cidaon, Taman Nasional Ujung Kulon, Info Hutan 2 (3): 193-204. [Indonesian]

LampaS, Gruber B, Henle K, Hoehn M. 2008. An optimisation approach to increase DNA amplification success of otter faeces. Conserv Genet 9:201-210.

Lukas D. 2008. Comparative Study of Genetic Variation and Relation to Social Structure of animals, Dissertation, Der Fakultät für Biowissenschaften, Pharmazie und Psychologie der Universität Leipzig, Germany.

Matsubayashi H, Hanzawa K, Kono T, Ishige T, Gakuhari T, Lagan P, Sunjoto I, Sukor JRA, Sinun W, Ahmad AH. 2014. First molecular data on Bornean banteng Bos javanicus lowi (Cetartiodactyla, Bovidae) from Sabah, Malaysian Borneo. Mammalia 78 (4): 1-9.

Moßbrucker AM, Apriyana I, Fickel J, Imron MA, Pudyatmoko S. 2015. Non-invasive genotyping of Sumatran elephants: implications for conservation The Sumatran elephant (Elephas maximus sumatranus) is one of three currently recognized subspecies. Trop Conserv Sci 8: 745-759.

Mondol S, Karanth KU, Kumar NS, Gopalaswamy AM, Andheria A, Ramakrishan U. 2009. Evaluation of non-invasive genetic sampling methods for estimating tiger population size. Biol Conserv 142 (10): 2350-2360.

Nater A, Arora N, Greminger MP, van Schaik CP, Singleton I, Wich SA, Fredriksson G, Perwitasari-Farajallah D, Pamungkas J, Krützen M. 2013.Marked population structure and recent migration in the critically endangered Sumatran Orangutan (Pongo abelii). J Heredity 104 (1): 2-13.

Peraturan Menteri Kehutanan Republik Indonesia Nomor P.58/MenhutII/2011, 2011. Strategi dan Rencana Aksi Konservasi Banteng (Bos javanicus) Tahun 2010-2020. Departemen Kehutanan RI, Jakarta. [Indonesian]

Pudyatmoko S, Djuwantoko. 2006. Sex ratio, herd size and composition and sexual segregation in banteng in the Baluran National Park, Indonesia. J Biol Sci 6 (2): 370-374

Pudyatmoko S, Djuwantoko, Sabarno Y. 2007. Evidence of Banteng (Bos javanicus) decline in Baluran National Park, Indonesia. J Biol Sci 7 (6): 854-859.

Pudyatmoko S. 2017, Free-ranging livestock influence species richness, occupancy, and daily behaviour of wild mammalian species in Baluran National Park, Indonesia. Mammal Biol 86: 33-41.

Sawaimul AD, Sahare MG, Ali SZ, Sirothia AR, Kumar S. 2014. Assessment of genetic variability among Indian sheep breeds using mitochondrial DNA cytochrome-b region. Vet World 7 (10): 852-855.

Sawitri R, Takandjandji M, Zein MSA, Rianti A. 2014. Keragaman genetik dan distribusi haplogrouptrenggiling (Manis javanica Desmarest, 1822). Jurnal Hutan dan Konservasi Alam,11 (2): 113125. [Indonesian]

Sawitri R, Zein MSA, Takandjandji M, Rianti A. 2014. Keragaman Genetik Banteng (Bos javanicus d'Alton) dari Berbagai Lembaga Konservasi dan Taman Nasional Meru Betiri. Jurnal Hutan dan Konservasi Alam 11: 155-159. [Indonesian]

Waits LP, Paetkau D. 2005. Noninvasive genetic sampling tools for wildlife biologists: A review of applications and. recommendations for accurate data collection. J Wildl Manag 69 (4): 1419-1433.

Whitten T, Soeriaatmaja RE, Afiff SA. 1996. The Ecology of Java and Bali. The Ecology of Indonesia Series. Volume II. Periplus Editions, Hongkong.

Wisesa AANG, Pemayun TGO, Mahardika IGNK, 2012. Analisis sekuens D-Loop DNA mitokondria. Indonesia Medicus Veterinus 1 (2): 281292. [Indonesian] 